\title{
Theoretical Background for Learning Outcomes Based Approach to Vocational Education
}

\author{
Gunta Kinta \\ University of Latvia, Latvia
}

\begin{abstract}
Due to the rapid development of technologies, changes in labour market and globalization, learning outcomes have become topic of debate in the European education policy. In this context knowledge, skills and competences an individual can demonstrate are more important than particular education programme or institution that has issued qualification. The concept of learning outcomes is seen as a tool for promoting international comparability of qualifications and mobility of labour force. This paper outlines the theoretical ideas that have formed the understanding and use of learning outcomes in vocational upper-secondary education. First, the taxonomy of educational objectives, which consists of three domains arranged in a hierarchical order - cognitive, affective, and psychomotor domain, - is described. This taxonomy is useful when learning outcomes should represent stages of various complexity or mastery. Second, three major learning theories - behaviourism, cognitivism and constructivism - are explored to clarify, which principles suggested by them could be applied in learning outcomes based vocational education. Third, learner-centred approach is explored as its principles may be supported by the use of learning outcomes. Both approaches require that students are active participants who want to learn and manage their own learning.
\end{abstract}

\section{Introduction}

According to the European education policy agenda, the introduction of learning outcomes based approach to vocational education has been set as one of the education policy priorities in Latvia. These political requirements were stated because of developments in the international economy and labour market. In rapidly changing employment situations, individuals have to be flexible, make independent decisions and assume more responsibility for their learning. In labour market more important aspect was to determine what employees or potential employees know, understand and can do. Learning outcomes could be used for clearly describing individual's knowledge, skills and competences.
Prior the shift towards learning outcomes, the concept and role of learning outcomes in vocational education should be explored. Careful study would indicate the most appropriate ways how to introduce learning outcomes in the Latvian vocational education system. On global scale, the term of learning outcomes is not new, and it may appear in various ideological and theoretical contexts. However, in the Latvian education, particularly in vocational education context, learning outcomes approach has not been thoroughly analysed.

Therefore, this paper is aimed at summarizing the major theoretical ideas and principles that could support the learning outcomes based approach. The ideas explored here are not exclusive and their list is not complete, but the most significant principles were selected. Although the main focus is vocational upper-secondary education, the theoretical background could refer to other fields of education, as well.

\section{Main principles of learning outcomes approach}

Learning outcomes in this paper are defined as statements of what a learner knows, understands and is able to do when completing a certain period of learning [12]. Thus, learning outcomes describe nonmaterial benefits students acquire during their learning.

The major differences regarding the definition of terms lie in categories or elements learning outcomes describe - knowledge, skills, abilities, attitudes, competences, values etc. The most frequently three categories are used - knowledge, skills and competences, - because these are considered to be measurable [12].

Knowledge is defined as a set of cognitive items forming in various contexts [26]. Knowledge imparts the ability to perceive data or information, create meaningful links and relate the new information with past experiences, as well as foresee future situations. Perceived information may not be considered as knowledge, but knowledge is created with the help of individual's cognitive operations [20].

Skills are explained as an ability to carry out a task or action in order to find solutions; thus, skills are based on knowledge that allows analysing and solving problems [20]. Skills include the ability to 
perform cognitive and practical operations acquired in different life and work situations [26]. Skills may be obtained during repeated practical and purposeful activities as a reaction towards some external requirements [22].

Competences focus on the manner how knowledge and skills obtained are used in various contexts [26]. Competences are acquired and developed through practice in studies, life and work. The term of competence has caused the most of discussions. One of the questions is whether competence or learning outcomes is more general concept to describe qualifications referred to the European Qualifications Framework [17]. On one hand, in some contexts competence is explained as the acquisition of skills or performing specific tasks according to previously formulated standards. On the other hand, competence is considered as ability in a wide professional field, i.e. competence is a holistic term imparting knowledge and skills [6]. These two approaches create confusion about terminology, which occasionally is increased due to various national contexts. In this paper and also in the European Qualifications Framework competence is seen as one of the categories describing expected learning outcomes.

As the most crucial features of learning outcomes could be mentioned:

- Learning outcomes are defined in advance of learning;

- Learning outcomes achieved are certified by demonstrating;

- Learning outcomes are measurable or observable;

- Learning outcomes are clear and understandable for all participants of education process;

- Learning outcomes are achievable during the particular period of learning;

- Learning outcomes indicate the individual progress of learners.

Statements of learning outcomes should be observable and clearly formulated before the period of education, for students and teachers to be certain whether and at what level the expected learning outcomes have been achieved.

According to the political standpoint, learning outcomes are already used in the Latvian vocational education, since state education standards and occupational standards outline knowledge, skills and professional competence to be obtained in education programmes. Moreover, vocational education programmes as such always have been learning outcomes oriented since labour market requires employees with particular abilities [4]. However, the presence of some elements of learning outcomes in education planning documents does not ensure that learning outcomes approach is applied in classroom. When using learning outcomes in education, approach to the education planning and implementation should be altered by ensuring that students to a certain extent achieve expected learning outcomes. Learning outcomes based education has the following characteristics:

- Focuses of students' ability to learn in order to ensure continuous and independent development of personality [24];

- Describes outcomes that should be achieved by a successful learner;

- Uses tools to determine what and to what extent students has learnt and acquired;

- Seeks for ways how to help students learn and achieve the expected outcomes;

- Explains why students should learn and acquire expected outcomes [7];

- Emphasizes learner centred approach to education [4];

To conclude, learning outcomes may be used as a tool for promoting more successful students' learning, and ensuring clear description of knowledge, skills and competences students may obtain or improve in the particular study course or education programme.

\section{Emergence of learning outcomes approach}

An increasing attention to the learning outcomes or competence oriented education may be observed since 1950-ties. Initially outcomes-based education programmes were introduced in the USA, but similar processes could be noted also in Australia and Canada. In 1980-ties and 1990-ties outcomes based education was wide-spread in many countries [13].

Regardless the rapid rise in popularity, the approach received some critics, for example, using only measurable learning outcomes that excluded such concepts as values and beliefs [8]; defining broad outcomes challenged the traditional curriculum division in study subjects and created confusion in educational planning and students' assessment [13].

In vocational upper-secondary education shift towards learning outcomes is related to the changes in work organization, technological development and the emergence of knowledge-based society. In 1980ties, industrial mass production, when employees had a strict division of duties and performed single tasks under a supervision of a manager, lost its significance. With the development of technologies and multi-disciplinary industries, team work with wider employees' functions and roles was emphasised. Employees needed to possess knowledge and understanding of entire production process to be able to take responsibility and make decisions [17]. Work duties could be integrated, as technological innovations allowed performing more complicated actions in a shorter time with less human resources [15]. As result, vocational education had to be changed in terms of content and form to adapt to labour market requirements. 
According to the study of Cedefop (European Centre for the Development of Vocational Training) in 32 European countries, in the majority of the national vocational education systems a shift towards learning outcomes based approach could be observed. This process is conducted either as an integral part of vocational qualifications system or as a driver for educational reforms [6].

Another Cedefop's study [5] revealed four main points of rationale for introducing learning outcomes in the national vocational education systems. First, new didactical and pedagogical ideas about learning suggested conducting certain changes in education process. Second, socio-economic reasons exist to ensure closer links between vocational education sector and labour market. Third, the reasons related to the effectiveness of vocational education management, funding and implementation may be source for changes. Fourth, the significance of increasing mobility and international comparability require some reforms to adapt national education systems to the European tools, e.g. the European Qualifications Framework, the European Credit System for Vocational Education and Training [5].

Reviewing the emergence of learning outcomes approach, its introduction seems to be logical step in the development of education systems. Shift towards learning outcomes is rather complicated measure and process of large scale; therefore, reforms in education should be carefully planned and involve all stakeholders.

\section{Theoretical background for learning outcomes based approach}

This paper focuses on three theoretical standpoints that have somehow influenced learning outcomes based approach: taxonomy of educational objectives, learning theories and learner-centred education.

\subsection{Taxonomy of educational objectives}

When describing the levels of learning outcomes, i.e. reflecting students' performance in a certain sequence of increasing difficulty, usually Bloom's taxonomy [2] is applied. As this taxonomy or classification since its creation in 1950-ties has experienced serious evaluations and revisions, e.g. $[25 ; 1]$, involving several researchers, more accurate title would be the taxonomy of educational objectives. The taxonomy consists of three hierarchically arranged systems representing three domains - cognitive, affective and psychomotor that are impacted in learning process (see Figure 1).

In 1950-ties, a group of psychology scientists supervised by Bloom explored pupils' work in class to find out which intellectual operations are essential in learning. To demonstrate deliberate mental actions of pupils, the scientists elaborated a classification system of six hierarchical levels defined as measurable learning objectives. Each level represents a cognitive function that is mastered in course of learning [2].

\begin{tabular}{|c|c|c|}
\hline $\begin{array}{c}\text { Cognitive } \\
\text { domain }\end{array}$ & $\begin{array}{c}\text { Affective } \\
\text { domain }\end{array}$ & $\begin{array}{c}\text { Psychomotor } \\
\text { domain }\end{array}$ \\
\hline 6. Evaluation & $\begin{array}{c}\text { 5. Internalizing } \\
\text { values }\end{array}$ & 7. Origination \\
\hline 5. Synthesis & 4. Organizing & 6. Adaptation \\
\hline 4. Analysis & 3. Valuing & $\begin{array}{c}\begin{array}{c}\text { 5. Complex } \\
\text { overt responses }\end{array} \\
\end{array}$ \\
\hline 3. Application & 2. Responding & 4. Mechanism \\
\hline 2. Comprehension & 1. Receiving & $\begin{array}{c}\text { 3. Guided } \\
\text { response }\end{array}$ \\
\hline \multirow[t]{2}{*}{ 1. Knowledge } & & 2. Set \\
\hline & & 1. Perception \\
\hline
\end{tabular}

The cognitive domain includes the following six levels:

1. Knowledge - refers to the recalling of ideas, things and phenomena, i.e. individual can save certain information in their memory and member it later, sometimes with minor changes;

2. Comprehension - involves understanding of figurative meaning; an individual understands the meaning of received information and considers whether to change their reaction in order to reply appropriately;

3. Application - includes ability to use previously obtained material in new situation or situations with new elements; an individual is able to solve unexpected problem or apply previously unused solution for familiar issue;

4. Analysis - involves dividing information in smaller parts and finding links between these parts; analysis is like a means for full understanding of things;

5. Synthesis - includes uniting of separate elements and forming a whole concept; synthesis has an aspect of creativity with certain limitations;

6. Evaluation - imparts making judgements, e.g. about values, ideas, works, solutions; criteria and standards are used to estimate accuracy and relevance of details [2].

The activities on each level are characterised by particular verbs. These verbs are highly essential when formulating learning outcomes as they assist in indicating the complexity of actions. Yet the verbs in 
various levels may overlap; therefore, the additional context should be provided in the statements of learning outcomes.

The classification was revised several times; the most evident alterations were introduced in 1990-ties by researchers under the supervision of Anderson and Krathwohl. To adapt the taxonomy to the present requirements of education and new ideas in pedagogy, the titles of levels were changed to verbs and two upper levels were switched; thus, the new levels are: remember, understand, apply, analyse, evaluate and create $[1 ; 18]$.

On basis of later studies, Bloom and colleagues developed classification of affective domain consisting of five levels. This domain refers to emotional aspects of learning; and levels, additionally to the increasing complexity of emotional actions, are underpinned by personal characteristics and conscience [16]. The levels are also reflected with verbs that characterize emotional operations developed in education process.

The affective domain has the succeeding five levels:

1. Receiving - imparts that an individual is aware of something, takes into account particular situation, phenomenon or thing; concerns also willingness receive information;

2. Responding - refers to individual's motivation, who is not only willing to participate, but also is active learning participant;

3. Valuing - denotes value of something; individual's behaviour is sufficiently consistent and stable to be called an opinion or attitude; operations vary from accepting values to choosing and following them;

4. Organizing - includes the stage after the inclusion of values; an individual has to solve issues that are related to several values; therefore, values need to be organized in a system by determining links between values and forming the dominating values; values are compared, linked and synthesised;

5. Internalizing values - imparts actions, which an individual performs in accordance with their internal values; behaviour is consistent, foreseeable and characteristic to the individual, whose opinion, ideas and attitudes are integrated in united perception of the world [16].

Bloom and colleagues initiated working with psychomotor domain that addresses motor skills, activities with materials and objects, but the researchers did not develop domain's detailed outline. Psychomotor domain usually may be applied through practical works, arts, music, theatre and sports [11]. Practical and work-based learning is crucial in vocational education.

Several authors have further developed Bloom's ideas about psychomotor domain, for an instance, Simpson designed classification of seven levels [11].
The physical actions performed on each level are characterized by certain verbs.

The psychomotor domain consists of the following seven levels:

1. Perception - involves the ability to use sensory organs to guide motor operations;

2. Set - refers to individual's readiness to commence particular operations, which impart physical, emotional and cognitive aspects;

3. Guided response - related to individual's ability to imitate; the accuracy of this ability may be evaluated according to particular criteria;

4. Mechanism - involves acquired responses, which have become habitual, individual's movements show some certainty and mastery;

5. Complex overt responses - involve skilful performance of motor operations including complex movements; mastery appears in fast, precise and coordinated work execution requiring minimum energy; responses are automatic;

6. Adaptation - imparts developed skills at such level that an individual is able to change their movement structure in order to adapt to specific requirements or solve a problem;

7. Origination - implies creating new movement structures to adapt to particular situation or problem; at this level creativity based on highly developed skills is emphasised [11].

Quite often researchers and practitioners, when dealing with learning outcomes, focus on the cognitive domain supporting the view that it is the most essential in learning. However, in the course of time the original Bloom's ideas have been subjected to discussions and changes regarding the current needs; therefore, the taxonomy should be explored in the relevant context and taking into account all three domains. The use of ideas implied by three domains for writing learning outcomes ensures more versatile education process. This aspect is particularly important in vocational education - parallel to the acquisition of professional knowledge, skills and competences, it should provide general development of students' personality.

\subsection{Learning theories in the context of learning outcomes}

The use of learning outcomes in vocational education is based on various learning theories. According to Cedefop's [5] study, one of the reasons for introducing learning outcomes approach was developments in didactics and pedagogies [5]. The most influential theories of learning outlined in the following paragraphs are behaviourism, cognitivism and constructivism. Although other learning theories, e.g., sociocultural learning, activity learning, have gained an increasing importance, their analysis was not included in this paper due to its limited volume. Major features of the learning theories are 
summarised in Table 1 below, using several sources of literature [23, 19, 27, 21].

Table 1. Comparison of learning theories $[23,19,27,21]$

\begin{tabular}{|c|c|c|c|}
\hline & Behaviourism & Cognitivism & Constructivism \\
\hline Founders & $\begin{array}{l}\text { Pavlov, Watson, Skinner, } \\
\text { Thorndike }\end{array}$ & Chomsky & $\begin{array}{l}\text { Dewey, Vygotsky, Bruner, } \\
\text { Piaget, von Glasersfeld }\end{array}$ \\
\hline $\begin{array}{l}\text { Ground } \\
\text { principle }\end{array}$ & $\begin{array}{l}\text { Observation and change of } \\
\text { students' behaviour; } \\
\text { repetition of favourable } \\
\text { behaviour until it becomes } \\
\text { automatic }\end{array}$ & $\begin{array}{l}\text { Cognitive processes } \\
\text { determining behaviour; } \\
\text { changes in behaviour } \\
\text { indicate activity of } \\
\text { cognitive operations }\end{array}$ & $\begin{array}{l}\text { On basis of experience and } \\
\text { cognitive schemes, } \\
\text { individual constructs their } \\
\text { own perception of world }\end{array}$ \\
\hline $\begin{array}{l}\text { Learning } \\
\text { is... }\end{array}$ & $\begin{array}{c}\text { Relevant response } \\
\text { (particular behaviour) to } \\
\text { external stimuli. } \\
\text { Teacher should create } \\
\text { appropriate learning } \\
\text { environment for students to } \\
\text { react in a certain manner }\end{array}$ & \begin{tabular}{|c|} 
Process of creating \\
knowledge; acquiring \\
meaning of phenomena. \\
Teacher should make \\
information meaningful to \\
help students organizing \\
and relating new \\
information to the previous \\
knowledge
\end{tabular} & $\begin{array}{c}\text { Interpretation of external } \\
\text { world on basis of individual } \\
\text { experience; creating } \\
\text { meaning and understanding } \\
\text { of phenomena. } \\
\text { Teacher should arrange } \\
\text { real-life tasks to be } \\
\text { performed in authentic } \\
\text { environment and help } \\
\text { students mastering } \\
\text { strategies of knowledge } \\
\text { construction } \\
\end{array}$ \\
\hline $\begin{array}{l}\text { Learning is } \\
\text { influenced } \\
\text { by... }\end{array}$ & $\begin{array}{c}\text { Environment } \\
\text { circumstances, instructions }\end{array}$ & $\begin{array}{c}\text { Environment, } \\
\text { circumstances; instructions; } \\
\text { operation of individual } \\
\text { cognitive processes; } \\
\text { individual's beliefs, values, } \\
\text { attitudes }\end{array}$ & $\begin{array}{c}\text { Interaction between } \\
\text { individual and environment } \\
\text { (including other } \\
\text { individuals); context }\end{array}$ \\
\hline $\begin{array}{l}\text { Potential } \\
\text { application }\end{array}$ & $\begin{array}{c}\text { Acquisition of simple, daily } \\
\text { knowledge or motor skills } \\
\text { to be used in various } \\
\text { situations without evident } \\
\text { alterations }\end{array}$ & $\begin{array}{l}\text { Discussions, problem } \\
\text { situations, processing } \\
\text { information }\end{array}$ & $\begin{array}{c}\text { Acquisition of complex and } \\
\text { advanced knowledge, when } \\
\text { previous perceptions are } \\
\text { reviewed }\end{array}$ \\
\hline $\begin{array}{l}\text { Strong } \\
\text { points }\end{array}$ & \begin{tabular}{|} 
Clear objectives are \\
provided; fast acquisition of \\
necessary operations \\
regarding certain criteria
\end{tabular} & $\begin{array}{l}\text { Students acquire cognitive } \\
\text { operations for performing } \\
\text { certain functions }\end{array}$ & $\begin{array}{c}\text { By mastering the } \\
\text { interpretation of various } \\
\text { situations, students may act } \\
\text { more successfully in real } \\
\text { life situations }\end{array}$ \\
\hline $\begin{array}{l}\text { Weak } \\
\text { points }\end{array}$ & $\begin{array}{l}\text { Disregarding individual } \\
\text { differences; } \\
\text { oversimplifying cognitive } \\
\text { processes that impact } \\
\text { behaviour }\end{array}$ & $\begin{array}{c}\text { Students learn how to } \\
\text { operate, but not always } \\
\text { efficiently }\end{array}$ & $\begin{array}{l}\text { Not appropriate for } \\
\text { situations when discussing } \\
\text { various opinions is } \\
\text { undesirable }\end{array}$ \\
\hline $\begin{array}{l}\text { Similar to } \\
\text { learning } \\
\text { outcomes } \\
\text { approach }\end{array}$ & $\begin{array}{l}\text { Observation of students' } \\
\text { behaviour }\end{array}$ & $\begin{array}{l}\text { The acquisition of various } \\
\text { cognitive operations (also } \\
\text { ability to evaluate learning } \\
\text { skills), use of problem } \\
\text { situations }\end{array}$ & $\begin{array}{c}\text { Active students' } \\
\text { participation in learning, } \\
\text { relevant learning context, } \\
\text { previous experience }\end{array}$ \\
\hline
\end{tabular}

According to the principles of behaviourism, learning environment is the most crucial factor, because learning is explained as a response to external stimuli. Therefore, awards and punishments are important to develop or discard a certain module of students' behaviour $[21 ; 19]$.
More attention is paid to monitoring students' behaviour without analysing the role of cognitive and affective aspects in learning. Thus, learning achievements are often seen as accommodating skills and recalling particular facts; students acquire such habitual behaviour that allows working quickly and 
correctly [19]. Students should master the ability to follow teacher's instructions fast and precisely, starting from simple to more complicated skills [21].

Learning outcomes based approach is said to overemphasise the observation of students' behaviour, i.e. if a learner is able to perform certain operations, they have achieved expected learning outcomes. This approach has been criticized because all knowledge, skills, competences, values and attitudes cannot be easily demonstrated during practical tasks. Therefore, principles of behaviourism may be applied when students should obtain some simple daily knowledge or motor skills, which may be used in new situations without significant changes, e.g., multiplication table, sewing a button or changing a car wheel. Thus, acquisition of such knowledge and skills involves memorizing facts and/or operations by repeatedly performing the same tasks.

Cognitivism partly developed as a natural opposition to behaviourism because behaviour of human cannot be stipulated only by some external stimuli. Cognitivism is focused on promoting cognitive operations. Yet both behaviourism and cognitivism emphasise the meaning of environment in learning, as well as instructions and correcting mistakes are important [21]. As result of cognitive operations, particular actions are performed; therefore, processing information, when structures, concepts and principles are organized in relevant cognitive schemes, is essential [19].

According to the principles of cognitivism, learning involves active students' participation within all the tasks for students to use their strategies for processing information and managing their learning. Thus, both cognitivism and constructivism consider a student to be an active participant, but in constructivism students not only process information, but also develop new meanings for this piece of information [21]. Previous knowledge and experience is crucial when creating new knowledge; and solving problems is seen as a context for construing knowledge [19].

Learning outcomes may include the acquisition of various cognitive operations, also an ability to evaluate one's own learning skills. The author supports the opinion that students need intentionally manage their learning to master expected learning outcomes. Yet as regards learning outcomes, formulating particular information processing strategies is not emphasised, but the ability to find the most appropriate solution to a problem. Problem situations, use of which is supported by cognitivism, may be applied in learning outcomes based vocational upper-secondary education.

In general constructivism is focused not only on developing cognitive strategies, but also on the interpretation of external world by creating new meanings for things and phenomena. According to behaviourism and cognitivism, world is real and forms external environment, while constructivism concentrates on construing the individual perception of world [21]. Students construct, not "receive" ready-made knowledge; this construing operation to great extent depends on previous knowledge and experience that students use in their learning [28].

Since students achieve expected learning outcomes in different speed and manner, learning is not linear, i.e. learning is irregular and unpredictable. Learning is both social and cultural activity occurring through interaction, when each participant contributes to the process [3]. When students interact, their learning is more productive than independent studies, as the learners involved share and discuss their varied previous experiences [28].

Unlike behaviourism, constructivism focuses on processing and interpreting information, not recalling facts or acquiring certain modules of behaviour. Learning should be organized in an authentic environment, and students should be provided with real-life tasks that would form relevant context for obtaining expected knowledge and skills [21]. In vocational education students' involvement in workbased learning at enterprises and school is an essential part of education programmes.

Principles of constructivism are said to be the most appropriate in learning situations when particularly complex knowledge has to be acquired. Regarding the new information, perceptions created in the previous learning experiences can be reviewed and, if need be, altered or discarded [21].

Learning outcomes based education similar to constructivism emphasizes the active students' participation in learning. Students acquire or improve their knowledge, skills and competences in a relevant learning context and on basis of their previous experience. The activity of students may be promoted by using problem solving situations.

To conclude, none of the learning theories is right or wrong, because each of them imparts some ideas or principles that may be applied in education. For an instance, repeated actions, enforcement and feedback supported by behaviourism assist in widening learning and improving students' memory. Cognitivism focuses on cognitive operations for learning to be more than adapting certain modules of behaviour. Constructivism contributes to students' ability to face unpredictable and changing situations with unclearly formulated problems that may be solved with the means of imagination, discussion and cooperation [21]. Thus, each learning theory suggests some principle to be used in learning outcomes based vocational upper-secondary education. 


\subsection{Learner-centred approach}

When learning outcomes are used in vocational upper-secondary education, teacher and students should be equally active in learning process. According to the results of Cedefop's study [4] conducted in 32 European countries, the introduction of learning outcomes in vocational education programmes is closely linked with some aspects of learner-centred approach [4]. Therefore, the principles of learner-centred approach should be explored in more detail.

Learner-centred or progressive approach to education developed as an opposition to the traditional education practice or study subjectcentred or teacher-centred approach. Learner-centred approach emphasizes that students are individuals with varied needs and interests; more important are students as they are at present situation, not what they could become in future [10]. The direct object of learning is students since a teacher's aim is not a greater volume of education material and more successful learning on some abstract level, but learning occurring in particular situation when working with particular students. Therefore, learning should be a specific process [14], which in a way is a unique experience.

In the traditional approach, time is constant and learning is variable, which means that a lesson has a certain duration, but volume and essence of learning content to be acquired in this period change. Meanwhile, in the learner-centred approach learning becomes constant and time is a variable. Thus, the main focus is on the particular student and continuous assessment whether and when the student has achieved the expected learning outcomes, while providing necessary information in limited period of time assuming that all students are able to receive and process the information in the same speed becomes insignificant [14]. In learning outcomes based education certain time limits are set - the expected learning outcomes are defined for particular period of education and students' performance is assessed constantly and at the end of course or programme. Yet differences in students' learning, e.g. speed and methods, are accepted as natural.

With the introduction of learner-centred approach, roles of teacher and students change significantly. Learners are active participants of the education process, who want to learn and are natural discoverers and creators of new knowledge. Cooperation, group and project work dominate in studies; those involved in learning trust, support and learn from each other. Individual characteristics of students and their varied experiences are not only taken into account, but also are favourable, because differences make learning more interesting and allows the participants to acquire different experiences $[10 ; 14]$.
Teacher becomes like a consultant or manager of resources. Yet the issue concerning the extent of students' freedom in class is debated, since not all students may be considered to possess a responsible and motivated attitude towards their learning [10]. Moreover, students may appear reluctant when learner-centred approach is implemented. One of the reasons could be additional duties students acquire in learner-centred approach - students have to work more and display initiative. A new approach may seem to be threatening, because many issues are unclear, e.g. new duties, responsibilities, changes. Discarding the previous approach may create sense of loss, and students may miss the traditional approach when they had fewer responsibilities, and decisions were made by teachers. Since changes related to introducing learner-centred approach are large, the reforms should be introduced gradually, because students would not be able to accept some new forms of work or follow complex instructions characteristic to learner-centred approach without adequate preparation [28]. According to Darling [10], two main reasons for students' lack of curiosity and learning motivation can be stated: first, a negative previous learning experience, and, second, discrepancy exists between students' interests and actual learning content. Frequently students are interested in the issues, which cannot be framed in a single study subject or discipline [10]. This aspect raises an additional challenge to the usual curricula planning with study subjects.

Weimer [28] describes five major aspects of change in education when learner-centred approach is introduced. Firstly, balance of power is influenced, because in learner-centred approach emphasis is on students' ability to learn, not teacher's ability to teach and give instructions. Secondly, functions of education content change in terms of previous learning experience and volume of learning content, i.e. more important is what students actually acquire, not the content explained by a teacher. Thirdly, as mentioned before, the role of teacher alters crucially - teacher is like a consultant that assists students in their learning. Fourthly, the responsibility for learning changes, because students have to assume full responsibility for their learning. Fifthly, the aim and process of students' assessment changes - the main function is to ascertain with the help of varied assessment methods that students in fact have achieved expected learning outcomes [28].

Both in learner-centred and learning outcomes approaches the control of learning is divided between teacher and students. The students are expected to assume responsibility and manage actively their own learning because teachers or parents cannot learn instead of students. Using learning outcomes in vocational upper-secondary education planning, implementation and students' assessment provides substantial support for a successful implementation 
of learner-centred approach. Thus, learning outcomes may be considered as a valuable tool for introducing and applying learner-centred approach to education.

\section{Conclusions}

Learning outcomes are statements, which describe what a learner knows, understands and is able to do when completing a certain period of education. Learning outcomes are expressed in three categories - knowledge, skills and competences. Although vocational education programmes always have been outcomes oriented, to apply learning outcomes approach completely, changes both in education planning and implementation have to be conducted. In learning outcomes based education expected outcomes are clearly formulated for all education process participants, as learning outcomes should serve as guidelines for managing learning and teaching.

Learning outcomes based approach to vocational upper-secondary education emerged due to the changes in work organization and the development of knowledge society. Learning outcomes were more appropriate for raising students' and graduates' awareness of their knowledge, skills and competences, as well as helped in gaining more independence and flexibility when individuals planned their learning.

To describe learning outcomes in a system of increasing complexity, the most frequently Bloom's [2] taxonomy is applied. Since the original taxonomy has been reviewed and complemented over the decades, at present this classifications should be referred as the taxonomy of educational objectives. The taxonomy of educational objectives imparts three domains arranged in a hierarchical system: cognitive domain with six levels [2;1], affective domain with five levels [16], and psychomotor domain with seven levels [11]. The use of all three domains when writing learning outcomes ensures a holistic approach to education for general development of students' personality.

The greatest attention is paid to three learning theories - behaviourism, cognitivism and constructivism. Although these theories represent different views about the process of learning, some of their principles and ideas may be used in learning outcomes based education. For example, the principles of behaviourism apply to cases when some simple knowledge or motor skills used in routine situations have to be acquired. Regarding cognitivism, expected learning outcomes are related to the acquisition of some cognitive operations or strategies; students have to manage their learning by providing the most appropriate solutions. The ideas supported by constructivism are more useful when particularly complicated knowledge has to be mastered and when previous perceptions and opinions need to be critically reviewed and analysed. According to constructivism, previous students' experience is highly important, as well as their mutual cooperation; learning should include authentic tasks and context, which in vocational upper-secondary education is ensured during the work-based learning in enterprises.

In learner-centred approach, students are active participants who want to learn, which agrees with and learning outcomes based education. The most often mutual cooperation, project and group work as methods are used. The cooperation between participants becomes more interesting when learners along with their individual characteristics have different previous experiences. The focus in education is on the particular student in the particular situation and regular assessment whether the expected learning outcomes have been achieved. Since the introduction of learner-centred approach involves substantial reforms in education process, the changes should be conducted gradually for both students and teachers to adapt to their new roles. Learning outcomes may serve as a useful means when introducing and implementing learner-centred approach to vocational upper-secondary education.

\section{References}

[1] Anderson, L.W., D.R. Krathwohl (eds.), A Taxonomy for Learning, Teaching, and Assessing: A Revision of Bloom's Taxonomy of Educational Objectives, Longman, New York, 2001.

[2] Bloom, B.S. (ed.), Taxonomy of Educational Objectives, the Classification of Educational Goals Handbook I: Cognitive Domain, McKay, New York, 1956.

[3] Butt, Gr., Making Assessment Matter, Continuum International Publishing Group, Great Britain, 2010.

[4] Cedefop, Curriculum Reform in Europe: The Impact of Learning Outcomes, Research paper, No 29, Publications Office of the European Union, Luxembourg, 2012.

[5] Cedefop, Learning Outcomes Approaches in VET Curricula: A Comparative Analysis of Nine European Countries, Office for Official Publications of the European Communities, Luxembourg, 2010.

[6] Cedefop, The Shift to Learning Outcomes: Policies and Practices in Europe, Office for Official Publications of the European Communities, Luxembourg, 2009.

[7] Ch. Acharya, "Outcome-based education (OBE): A New Paradigm for Learning", CDTLink, 7/3, 2003, accessed 24.03.2012, http://www.cdtl.nus.edu.sg/link/nov 2003/obe.htm.

[8] D. Brady "Competence-Based Education", In: McKenzie, P., Ph. Mitchell, and P. Oliver (eds.), Competence and Accountability in Education, Arena, Great Britain, 1995, pp. 1-18. 
[9] D. Kennedy, Á. Hyland, and N. Ryan, "Writing and Using Learning Outcomes: A Practical Guide", EUA Bologna Handbook, Section C 3.4-1, 2007, pp. 1-30.

[10] Darling, J., Child-Centred Education and Its Critics, Paul Chapman Publishing Ltd, England, 1994.

[11] E.J. Simpson, "The Classification of Educational Objectives: Psychomotor Domain", Illinois Journal of Home Economics, 10/4, 1966, pp. 110-144.

[12] European Parliament and Council, "Recommendation on the Establishment of the European Qualifications Framework for Lifelong Learning", Official Journal of the European Union, C 111/1, 6.05.2008.

[13] Hargreaves A., L. Earl, Sh. Moore, and S. Manning, Learning to Change: Teaching Beyond Subjects and Standards, Lyons Falls Turin Book, USA, 2001.

[14] Harris, M., R. Cullen, Leading the Learner-Centred Campus: An Administrator's Framework for Improving Student Learning Outcomes, Jossey-Bass, USA, 2010.

[15] J. Virkkunen, E. Makinen, and L. Lintula, "From Diagnosis to Clients: Constructing the Object of Collaborative Development between Physiotherapy Educators and Workplaces", In: Daniels, H., A. Edwards, Y. Engeström, T. Gallagher, and S.R. Ludvingsen (eds.), Activity Theory in Practice: Promoting Learning across Boundaries and Agencies, Routledge, Great Britain, 2010, pp. 9-24.

[16] Krathwohl, D.R., B.S. Bloom, and B.B. Masia, Taxonomy of Educational Objectives, the Classification of Educational Goals - Handbook II: The Affective Domain, David McKay, New York, 1964.

[17] M. Brockmann, L. Clarke, and C. Winch, "Knowledge, Skills, Competence: European Divergences in Vocational Education and Training (VET) - the English, German and Dutch Cases", Oxford Review of Education, Volume 34, Issue 5, October 2008, pp. 547-567.

[18] M. Forehand, "Bloom's Taxonomy: Original and Revised", In: Orey, M. (ed.), Emerging Perspectives on Learning, Teaching, and Technology, 2005, accessed 24.07.2010,

http://projects.coe.uga.edu/epltt/index.php?title=Bloom $\% 27$ s_Taxonomy.

[19] M. James, "Assessment, Teaching and Theories of Learning”, In: Gardner, J. (ed.), Assessment and Learning, Sage, London, 2006, pp. 47-60.

[20] Nygaard, Cl., Cl. Holtham (eds.), Understanding Learning-Centred Higher Education. Copenhagen Business School Press, Denmark, 2008.

[21] P.A. Ertmer, T.J. Newby, "Behaviorism, Cognitivism, Constructivism: Comparing Critical Features from an Instructional Design Perspective", Performance Improvement Quarterly, 6/4, 1993, pp. 50-72.
[22] Proctor, R.W., A. Dutta, Skill Acquisition and Human Performance, Sage, Thousand Oaks, California, 1995.

[23] Schunk, D.H., Learning Theories: An Educational Perspective, 6th edition, Pearson Education, Inc, USA, 2012.

[24] St. Adam, "Learning Outcomes Current Developments in Europe: Update on the Issues and Applications of Learning Outcomes Associated with the Bologna Process", In: Bologna Seminar: Learning Outcomes Based Higher Education: the Scottish Experience, Edinburgh, Scotland, 21.-22.02.2008, accessed 21.01.2010, http://www.ond.vlaanderen.be/ hogeronderwijs/bologna/BolognaSeminars/documents/Edi nburgh/Edinburgh_Feb08_Adams.pdf.

[25] T.R. Guskey, "Closing Achievement Gaps: Revisiting Benjamin S. Bloom's "Learning for Mastery"”, Journal of Advanced Academics, 19/1, 2007, accessed 17.01.2010, http://www.eric.ed.gov/ERICDocs/data/ericdocs2sql/conte nt_storage_01/0000019b/80/3c/fe/ba.pdf.

[26] Vocational Education Administration, "Methodology for Development of Occupational Standards", In: ESF project Development of a Unified Methodology for the Quality Improvement of Vocational Education and Involvement and Education of Social Partners, Vocational Education Administration, Riga, 2007.

[27] Von Glasersfeld, E., Radical Constructivism: A Way of Knowing and Learning, The Falmer Press, Great Britain, 1995.

[28] Weimer, M., Learner-Centred Teaching, JosseyBrass, San Francisco, 2002.

\section{Acknowledgements}

This work has been supported by the European Social Fund within the project "Support for Doctoral Studies at University of Latvia". 